\title{
Development, stability and in vitro permeation studies of gels containing mometasone furoate for the treatment of dermatitis of the scalp
}

\author{
Ana Cristina Gomes Barros Salgado ${ }^{1,2}$, Alexandra Maria Nunes Nogueira da Silva ${ }^{3}$, Marta Cristina \\ Jorge Cabral Machado ${ }^{1,2}$, Maria Aida da Silva Costa Duarte ${ }^{3}$, Helena Margarida de Oliveira \\ Marques Ribeiro ${ }^{1,2, *}$
}

\author{
${ }^{1}$ iMed.UL -Research Institute for Medicines and Pharmaceutical Sciences, ${ }^{2}$ Laboratório de Tecnologia Farmacêutica, \\ Faculdade de Farmácia, Universidade de Lisboa, ${ }^{3}$ Laboratório de Controlo Microbiológic, Faculdade de Farmácia, \\ Universidade de Lisboa
}

\begin{abstract}
Dermatological inflammatory diseases such as atopic dermatitis, psoriasis and seborrhoeic dermatitis often affect the scalp and the eyebrows. Although there are many dosage forms available, these are particularly critical anatomic regions for application of topical formulations because of the presence of hair. Lotions are therefore the recommended type of drug delivery system for these areas. The presence of hair may limit the application and thus the acceptability of the formulation and its compliance. Because of its low apparent viscosity, lotion application is unpleasant. Gels, given their consistency and adhesiveness, are a suitable alternative to lotions in this situation. The aim of this study was to formulate a stable gel containing mometasone furoate, which is an anti-inflammatory and anti-pruritic corticosteroid, in order to improve topical treatment of scalp dermatitis. In this study, pharmaceutical development, physicalchemical characterization, stability and in vitro permeation studies were performed. In terms of the $\mathrm{pH}$, viscosity, assay and macroscopic and microbiological properties, the gel was stable over the period of study. The in vitro permeation studies allowed the characterization of the mometasone furoate permeation profile for the gel through different membranes. Mometasone furoate presented a slow permeation through the skin. This gel appears safe for topical application.
\end{abstract}

Uniterms: Dermatitis/ treatment. Mometasone furoate. Gel/development. Gels/stability. Skin permeation/ in vitro study.

\begin{abstract}
Afecções dermatológicas do tipo inflamatório como a dermatite atópica, psoríase e dermatite seborreica, afetam freqüentemente o couro cabeludo e sobrancelhas. Apesar de existirem várias formas farmacêuticas para o seu tratamento, apenas as loções são indicadas para estas zonas, mas devido à baixa viscosidade, a aplicação de loções torna-se desagradável. Os geles, pela maior consistência e capacidade de adesão, apresentam-se como alternativa nesta situação. Neste trabalho procedeu-se ao desenvolvimento galênico de um gel com furoato de mometasona, que é um potente corticóide de última geração, com um rácio melhorado de risco/benefício. Foram avaliadas as características físico-químicas, a estabilidade e foram realizados ensaios de permeação in vitro. O gel obtido apresenta características organolépticas e reológicas adequadas ao fim a que se destina tendo-se apresentado estável química, física e microbiologicamente durante o tempo do ensaio. Os estudos de permeação in vitro permitiram caracterizar a formulação através de diferentes membranas. A membrana biológica (pele) não permite uma grande permeação do fármaco o que poderá sugerir que esta formulação é segura para aplicação tópica.
\end{abstract}

Unitermos: Dermatite/tratamento. Furoato de mometasona. Gel/desenvolvimento. Gel/estabilidade. Permeação cutânea/estudo in vitro.

\footnotetext{
*Correspondence: H. M. Ribeiro. iMed.UL - Research Institute for Medicines and Pharmaceutical Sciences, Faculdade de Farmácia da Universidade de Lisboa. Av. Prof. Gama Pinto, 1649 - 003 LISBOA, Portugal. E-mail: helena. ribeiro@ff.ul.pt
} 


\section{INTRODUCTION}

The most common types of dermatitis (inflammatory condition of the skin) include atopic dermatitis (also known simply as eczema), seborrhoeic dermatitis and psoriasis. Each of these conditions has an impact on quality of life and requires good compliance to therapy. (Agner, 2005; Thestrup-Pedersen, 2005). Typical symptoms of these diseases are inflammatory type rash, redness and itching (Koda et al., 2004). Drug therapy of the inflammatory states of the skin is mainly topical. This addresses the treatment of symptoms, since in most cases causal treatment is impossible due to unknown etiology. Topical corticosteroids are the most commonly used drugs in these skin conditions (Marks et al., 1973).

Although there are many dosage forms available for the treatment of skin disorders, only lotions have shown to be suitable for hairy areas (Hanifin et al., 2004). Compliance to the therapy depends, among other factors, on the acceptability of the dosage form. In such areas the hair makes application difficult and sometimes unpleasant and uncomfortable. Furthermore, the anatomic site should also be considered. For example eyebrows and neck require special care when applying liquid formulations as they tend to drain at these sites. Caution is particularly important when considering the application of liquid formulations of corticosteroids in regions close to the conjunctiva, which is a highly vascularized mucosa and thus promotes absorption (Agner, 2005; Thestrup-Pedersen, 2005). Permeation studies aim to determine the kinetic profile of the drug which reflects the changes in concentration over time and diffusion through the skin. Such studies are carried out to evaluate the permeation of drugs through the skin during the development of topical formulations as well as toxicity after dermal exposure.

Percutaneous absorption can be studied using in vitro tests. These are widely used in the preliminary phase of the evaluation of percutaneous absorption mainly due to cost factors, time and reproducibility. In vitro methods allow the use of synthetic membranes and animal or human skin (biological membrane), and contribute toward the reduction, refinement and replacement of in vivo testing. The in vitro experimental conditions should mimic in vivo conditions as closely as possible so that results can then be extrapolated (Hadgraft et al. 2005; Wiedersberget al., 2008). The diffusion of a molecule through a barrier is dependent on its physicochemical properties, such as partition and diffusion coefficients, solubility, and molecular weight. As the developed formulation is for topical ap- plication the permeation profile and drug concentration that crosses the barrier were determined. Mometasone furoate (MF) is a potent corticosteroid which presents an improved risk/benefit ratio. It is therefore of great value for inflammatory skin diseases, showing a strong anti-inflammatory action, rapid onset of action and low systemic bioavailability after topical application (Valotis, A., et al., 2004, Teng, XW et al., 2003).

The aim of this work was to prepare a gel formulation with $0.1 \%(\mathrm{w} / \mathrm{w})$ mometasone furoate for scalp dermatitis. The physicochemical and microbiological stability and in vitro permeation profile of mometasone furoate were evaluated.

\section{MATERIALS AND METHODS}

Since the aim of this study was to formulate an alternative dosage form to currently available lotions it was decided to keep the same excipient composition as those on the Portuguese market (Elocom ${ }^{\circledR}$ ScheringPlough). Hydroxypropyl methylcellulose was chosen as the thickener agent.

The final formulation was prepared with $1.5 \%$ hydroxypropyl methylcellulose (HPMC), obtained from Fluka ChemieGmbH, previously swollen in purified water, isopropyl alcohol FP VIII and propyleneglycol USP (40:40:20). The gel was packed in aluminium tubes.

\section{Physico-chemical characterization}

Macroscopic organoleptic characteristics (colour, odour, texture and appearance) were determined. The $\mathrm{pH}$ was controlled using a potentiometric method $(\mathrm{pH}$ meter Metrohm ${ }^{\circledR} \mathrm{pH}$ Meter 744, glass electrode). The apparent viscosity and rheological profile were evaluated using a Brookfield rotational viscometer ${ }^{\circledR}(\mathrm{RV}$ DV-II, SSA, needles SC4-21 and SC4-27).

High performance liquid chromatography (HPLC) with UV detection (UV) was used to assay the mometasone furoate in the formulation using a method adapted from a previous technique reported elsewhere in the literature (Marks, R. et al 1973). A chromatograph Merck - Hitachi (diode array detector, pump and software), with an Inertsil C8 - 5 $\mu \mathrm{m}-4.6 \times 150 \mathrm{~mm}$ column (GL Sciences) was used. The analysis was performed at room temperature. Test conditions were: mobile phase - Deionized water: methanol $(30: 70, \mathrm{v} / \mathrm{v})$, flow rate $-1.5 \mathrm{~mL} / \mathrm{min}$, Injection volume - $10 \mathrm{~mL}$, UV detection at $248 \mathrm{~nm}$. The experimental validation of the assay method was performed according to the guideline "Validation of Analytical Procedures: Text and Methodology (CPMP/ICH/381/95). 


\section{Microbiological characterization}

The microbiological stability assessment was performed according to the Pharmacopoeia VIII (5.1.4-control products do not necessarily sterile - category 2 ).

\section{Stability Evaluation}

The experimental protocol was based on the guideline "Stability testing: of existing active substances and related finished products" (CPMP/QWP/122/02). Three batches of the formulation were produced under similar conditions and were then stored at room temperature (realtime, $25 \pm 2{ }^{\circ} \mathrm{C} / 60 \% \pm 5 \%$ humidity ) for 1 year and submitted to accelerated aging for 180 days (oven at $40 \pm 2{ }^{\circ} \mathrm{C}$ $175 \% \pm 5 \%$ humidity). The stability of the formulation was defined as amounts of mometasone furoate of $90-110 \%$ without significant changes in other parameters. Samples were taken for analysis at the end of the following time periods: 7, 14, 21, 27, 41, 90, 180, 270 and 365 days.

\section{In vitro permeation studies}

Solubility studies of mometasone furoate were performed. The choice of the receptor phase was based on the solubility of the drug (mometasone furoate). Given the chemical characteristics of mometasone furoate (FPVIII), different mixtures of solvents were prepared as described in Table I. An excess of MF was added to each mixture. This test was performed in triplicate, always under magnetic stirring and at room temperature. After 48 hours, the resulting suspensions were centrifuged at $13000 \mathrm{rpm}$ for 10 minutes and aliquots of $200 \mu \mathrm{L}$ of supernatant were collected and diluted in $10 \mathrm{~mL}$ of methanol. These solutions were analyzed by HPLC.

TABLE I - Receptor phases prepared for the solubility tests.

\begin{tabular}{lcc}
\hline Receptor phase & Solvents & Proportion \\
\hline A & Ethanol : PBS pH 4.5 & $1: 1$ \\
B & Ethanol : PBS pH 4.5 & $1: 3$ \\
C & Ethanol : PBS pH 4.5 & $2: 3$ \\
D & Ethanol : Water & $1: 1$ \\
E & Ethanol : Water & $3: 1$ \\
\hline
\end{tabular}

In vitro permeation studies were performed using Franz cells of static flow with 2 types of membrane: silicone (Sil-Tec, ref 500-2, 0002", obtained from Technical Products Inc. of Georgia, USA), and biological membrane (human skin). The tissue came from a surgical intervention to reduce abdominal mass in a Caucasian of 54 years, after ethical approval and informed consent. After excision, the tissue was kept in saline solution at $2-8{ }^{\circ} \mathrm{C}$ and was then frozen at $-20^{\circ} \mathrm{C}$ until use. The stratum corneum (SC) and viable epidermis were obtained by a thermal process (OECD, 2004a) where the tissue was immersed for 45 seconds in a solution of isotonic phosphate buffer (PBS) at $\mathrm{pH} 7.4$ at $60 \pm 2{ }^{\circ} \mathrm{C}$. After this procedure the epidermis was removed. The area of the membrane in contact with the donor and receptor phases was approximately $1.0 \mathrm{~cm}^{2}$. The receptor compartment had a capacity of approximately $5.0 \mathrm{~mL}$. The receptor phase was an ethanol:water $(1: 1)$ mixture. The system was maintained at $32{ }^{\circ} \mathrm{C}$ for about 30 minutes before starting the experiment. Samples of $200 \mu \mathrm{L}$ were collected at predefined times. After sampling, the same volume was replaced with fresh receptor phase maintained at the same temperature. The tests were performed with 6 cells per formulation. The amount applied was about $200 \mathrm{mg}$ of gel (equivalent to $200 \mu \mathrm{g}$ of $\mathrm{MF}$ ). The amount of mometasone furoate was assayed by the high-resolution chromatography method with UV detection (HPLC/UV) described above. Flux, lag time and permeability coefficients were estimated.

\section{RESULTS}

\section{Physico-chemical Characterization}

The three lots of gel were transparent, uniform in appearance and presented an alcoholic smell.

The $\mathrm{pH}$ (Table II) did not significantly vary over time. Mometasone furoate is only stable at $\mathrm{pH} 4-4.5$ and so significant changes in $\mathrm{pH}$ of the gel would lead to instability of the formulations and entail their abandonment for not meeting the range of $\mathrm{pH}$.

TABLE II - pH values through 365 days (mean \pm SD, $n=3$ ).

\begin{tabular}{lcc}
\hline Time (days) & Room temperature & Oven \\
\hline 0 & $4.38 \pm 0.03$ & $4.34 \pm 0.06$ \\
7 & $4.35 \pm 0.02$ & $4.37 \pm 0.03$ \\
14 & $4.36 \pm 0.08$ & $4.36 \pm 0.01$ \\
27 & $4.35 \pm 0.07$ & $4.34 \pm 0.0$ \\
41 & $4.35 \pm 0.08$ & $4.34 \pm 0.03$ \\
60 & $4.36 \pm 0.06$ & $4.35 \pm 0.08$ \\
90 & $4.39 \pm 0.14$ & $4.40 \pm 0.13$ \\
180 & $4.62 \pm 0.10$ & $4.96 \pm 0.26$ \\
270 & $4.63 \pm 0.16$ & - \\
365 & $4.69 \pm 0.19$ & - \\
\hline
\end{tabular}


The rheological properties over time were studied to evaluate the gel's stability. Any change in the dispersion of particles, degree of flocculation or other changes in the structure of the gels can lead to changes in the rheological properties of the formulations. As shown in Figure 1, the viscosity of the three lots significantly increased during the first days. This increase in viscosity was caused by the swell of the polymer in the solvent, so that it could achieve a gel structure. After this time the viscosity did not significantly change (Figure 1). This gel was found to possess a pseudoplastic profile (Ferrão et al., 2007).

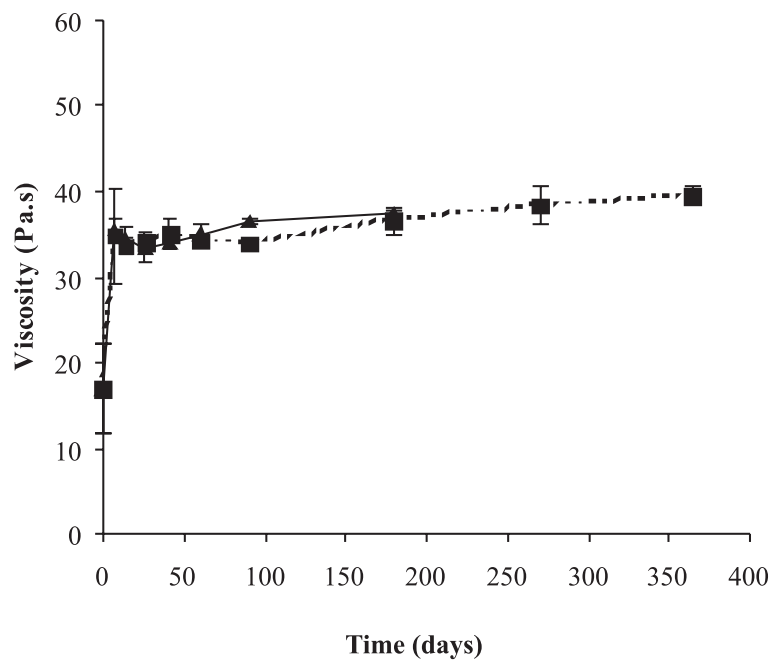

FIGURE 1 - Viscosity values in lots stored at room temperature (घ) and oven ( $\boldsymbol{\Delta})$, (mean $\pm \mathrm{SD}, \mathrm{n}=3$ ).

Mometasone furoate amounts did not significantly change over the study period (Figure 2 ) for the lots stored at room temperature. The content of mometasone furoate was higher than the specifications following storage in the oven and after 180 days $(109.6 \pm 3.7 \%)$. This variation may have been due to the solvent evaporation.

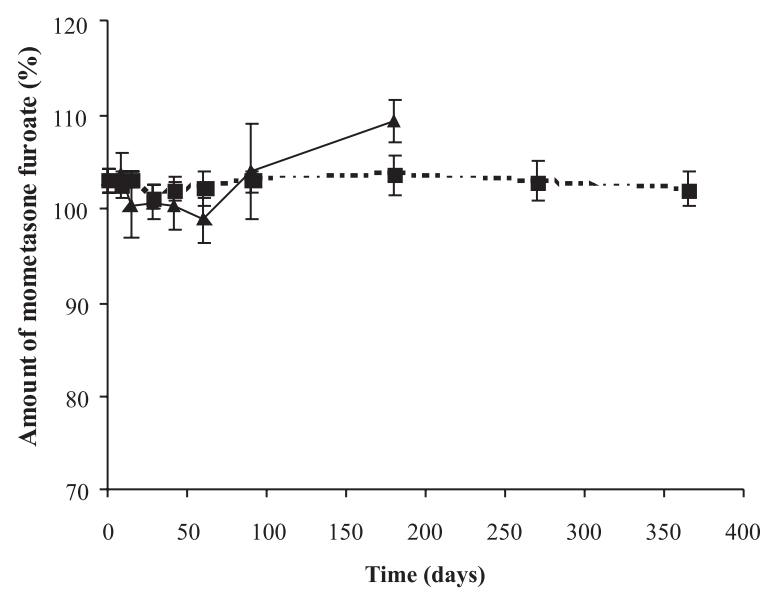

FIGURE 2 - Percentage of mometasone furoate in the lots stored at room temperature (- and in the lots stored in the oven $(\boldsymbol{\Lambda})$, (mean $\pm \mathrm{SD}, \mathrm{n}=3$ ).

The microbiological studies (Table III) showed that the results were within recommended limits of the specifications. This indicates that the gels kept effectively for the time they were tested.

\section{In vitro permeation studies}

The solubility of mometasone furoate is summarized in Table IV.

TABLE III - Microbiological results of the lots stored at room temperature and for the lots stored in the oven.

\begin{tabular}{|c|c|c|c|c|}
\hline \multirow{2}{*}{$\begin{array}{l}\text { Time } \\
(0,1,2,3,6,12 \text { months })\end{array}$} & \multicolumn{2}{|c|}{ Total aerobic microbial count } & \multirow[t]{2}{*}{ Yeast / mould count } & \multirow{2}{*}{$\begin{array}{c}\text { E. coli } \\
\text { P.aeruginosa } \\
\text { S.aureus }\end{array}$} \\
\hline & $30^{\circ} \mathrm{C}$ & $37^{\circ} \mathrm{C}$ & & \\
\hline Room temperature & conform & conform & conform & conform \\
\hline $40^{\circ} \mathrm{C} / 75 \% \mathrm{HR}$ & conform & conform & conform & conform \\
\hline
\end{tabular}

TABLE IV - Solubility of mometasone furoate in different solvents.

\begin{tabular}{lccc}
\hline Receptor Phase & Solvents & Proportion & Solubility $(\mu \mathrm{g} / \mathrm{mL})$ \\
\hline A & Ethanol : PBS pH 4.5 & $1: 1$ & 239.9 \\
B & Ethanol : PBS pH 4.5 & $1: 3$ & 30.4 \\
C & Ethanol : PBS pH 4.5 & $2: 1$ & 1119.5 \\
D & Ethanol : Water & $1: 1$ & 292.7 \\
E & Ethanol : Water & $1: 3$ & 1765.6 \\
F & Ethanol : Water & $3: 1$ & 24.0 \\
\hline
\end{tabular}


Table IV shows that mometasone furoate was more soluble in solvent mixtures E $(1765.6 \mathrm{~g} / \mathrm{mL})$ and $\mathrm{C}$ $(1119.5 \mathrm{mg} / \mathrm{mL})$. However, mixture $\mathrm{D}$ was selected as the receptor phase in these permeation studies. This mixture has the capacity to solubilize the drug. The OECD recommends a ratio of $1: 1(\mathrm{v} / \mathrm{v})$, since ethanol can evaporate during trials and interfere with results.

Permeation studies with synthetic membranes were performed for 24 hours whereas those with biological membranes lasted 48 hours. The results of the amount of mometasone furoate permeated (\%) through the silicone membrane and skin are shown in Table V.

TABLE V - Percentage of mometasone furoate through silicone membrane and human skin (mean $\pm \mathrm{SD} ; \mathrm{n}=6$ ).

\begin{tabular}{lcc}
\hline Membrane & \multicolumn{2}{c}{ Percentage of MF } \\
\cline { 2 - 3 } & 8 hours & 24 hours \\
\hline Silicone & $0.62 \pm 0.16$ & $1.43 \pm 0.43$ \\
Skin & $0.11 \pm 0.07$ & $0.36 \pm 0.06$ \\
\hline
\end{tabular}

The flux, lag time and permeability coefficients of MF through human skin are shown in Table VI.

TABLE VI - Flux, lag time and permeability coefficient (Kp) of mometasone furoate through skin membrane (mean $\pm \mathrm{SD} ; \mathrm{n}=6$ ).

\begin{tabular}{lcc}
\hline Flux $\left(\mu \mathrm{g} / \mathrm{cm}^{2} / \mathrm{h}\right)$ & Lag time $(\mathrm{h})$ & $\mathrm{Kp} * 10^{-5}(\mathrm{~cm} / \mathrm{h})$ \\
\hline $0.046 \pm 0.005$ & $1.40 \pm 0.617$ & $5.8 \pm 0.1$ \\
\hline
\end{tabular}

Comparing the results obtained with silicone membrane to those obtained with biological membrane (Figures 3 and 4) revealed that the flux was highest through the silicone membrane (Table V).

Permeation studies using the biological membrane revealed the percentage amount of mometasone furoate permeated as $0.81 \pm 0.11 \%$ (mean \pm standard deviation) after 48 hours. This low percentage of permeation can be explained by the fact that some evaporation of the vehicle may have occurred. It is also possible that crystals of the drug were formed. Moreover, the excipients of the gel may have higher fluxes than the drug thus delaying the permeation of the latter to the receptor phase. Perhaps the membrane (epidermis) acts as a reservoir, a phenomenon of corticoids described by some authors (Magnusson et al., 2006; Barbanti, 2006a). To test this hypothesis an extraction of the drug from the membrane was performed using methanol. The samples were analyzed by HPLC. The values obtained were around $0.028 \mu \mathrm{g}$ of mometasone furoate $(0.014 \%)$.

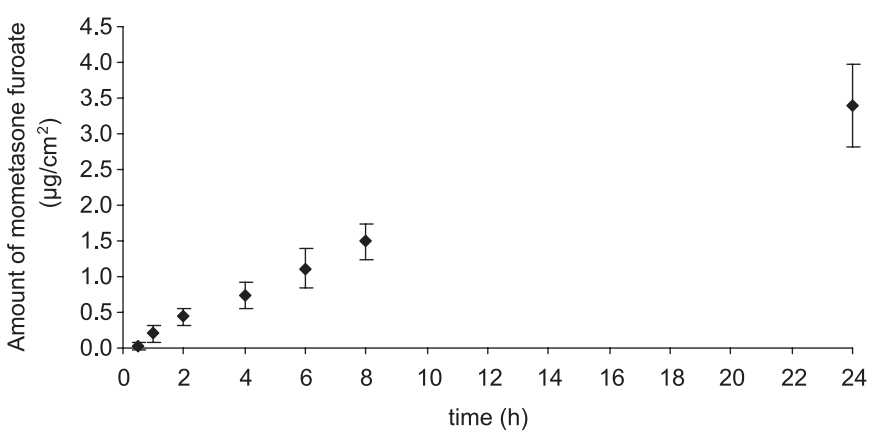

FIGURE 3 - Permeation profile of mometasone furoate for the formulation through the silicone membrane (mean $\pm \mathrm{SD}, \mathrm{n}=6$ ).

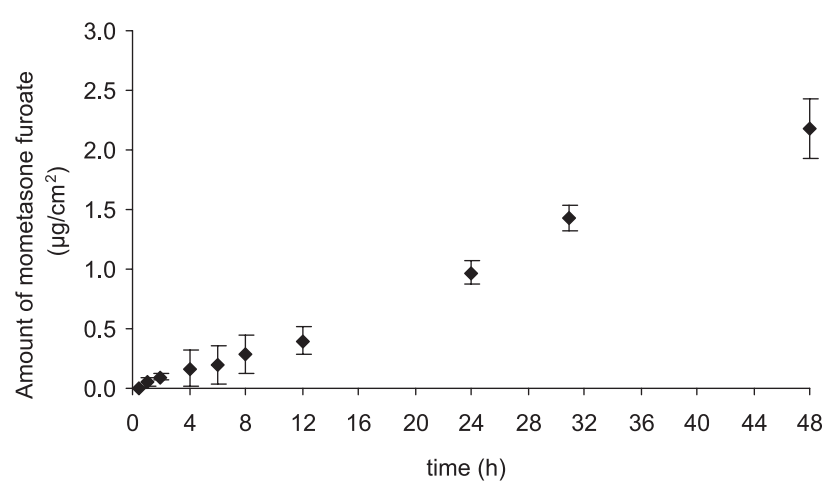

FIGURE 4 - Permeation profile of mometasone furoate for the formulation through the skin membrane (mean $\pm \mathrm{SD}, \mathrm{n}=6$ ).

These results suggest that the gel developed is safe for topical application as only $0.81 \%$ of the applied drug permeated through the human epidermis after 48 hours.

\section{CONCLUSIONS}

A gel containing $0.1 \%(\mathrm{w} / \mathrm{w})$ of mometasone furoate was developed. It presented suitable organoleptic characteristics for its purpose (dermatitis of the scalp). Stability studies showed that this formulation was chemically, physically and microbiologically stable for one year when stored at room temperature. The in vitro permeation studies were used to characterize the mometasone furoate permeation profile through different membranes. Biological membrane (human skin) did not allow a large permeation of the drug. In vivo studies, particularly bioavailability studies using Tape-Stripping techniques, should be conducted to confirm these results.

\section{REFERENCES}

AGNER, T. Compliance among patients with atopic eczema. Acta Derm. Venereol., n.215, supl., p.33-35, 2005. 
FARMACOPEIA PORTUGUESA VIII, Lisboa: INFARMED/ Ministério da Saúde e Instituto Nacional da Farmácia e do Medicamento, 2005. p.157-159.

FERRÃO, E.; SALGADO, A.; BRONZE, M. R.; RIBEIRO, H. Desenvolvimento e avaliação sensorial de formulações para aplicação no couro cabeludo. Rev. Lusóf. Ciên. Tec. da Saúde, v.4, n.1 p.242-250, 2007.

GUIDELINE EMEA. Stability testing: of existing active substances and related finished products. issued as CPMP/ QWP/122/02, 2003. p. 5-13.

GUIDELINE ICH. Q2 (R1), Validation of analytical procedures: Text and methodology. EU: Adopted by CPMP, November 94, issued as CPMP/ICH/381/95, 2005. p.2-15.

HADGRAFT, J.; LANE, M. Skin permeation: the years of enlightenment. Int. J. Pharmaceutics, v.305, n.1-2, p.2-12, 2005.

HANIFIN, J. M.; COOPER, K. D.; HO, V. C. Guidelines of care for atopic dermatitis, developed in accordance with the American Academy of Dermatology. J. Am. Acad. Dermatol., v.50, suppl. 3, p.391-404, 2004.

\section{HERKENNE C., NAIK A., KALIA Y. N., HADGRAFT J., GUY}

R. H. Dermatopharmacokinetic prediction of topical drug bioavailability in vivo. J. Invest. Dermatol., v.127, número?, p.887-894, 2007.

KODA, K.; YOUNG, L., KRADJAN W., GUGLIELMO J., ALLDREDGE B., CORELLI R., WILLIAMS B. Applied therapeutics: the clinical usage of drugs. 8.ed. Lippincott: Williams \& Wilkins, 2004. p.38-39.
MAGNUSSON B. M., CROSS S. E., WINCKLE G., ROBERTS M. S. Determination of in vitro permeability and tissue reservoir characteristics in human skin layers. Skin Pharmacol. Physiol., v.19, n.6, p.336-342, 2006.

MARKS, R.; PONGSEHIRUM, D.; SAYLAN, T. A method for the assay of topical corticosteroids. Br. J. Dermatol., volume?, n.88, p.69-74, 1973.

PELLANDAC. L. Topical bioavailability of glucocorticosteroids. Dermatopharmacokinetic and dermatopharmacodynamic of topically applied triamcinolone acetonide in humans. Basel, 2006. p.41-42. [Tese Doutoramento. Hospital Pharmacy. Universidade Basel].

TENG, X.W.; CUTLER, D. C.; DAVIES, N. M. Degradation kinetics of mometasone furoate in aqueous systems. Int. J. Pharmaceutics, v.259, n.1, p.129-141, 2003.

THESTRUP-PEDERSEN, K. Treatment strategies and compliance for the adult patient with atopic eczema, Acta Derm. Venereol., v.85, n.5, supl.215, p.36-40, 2005.

VALOTIS, A., NEUKAM K., ELERT O., HÖGGER P. Human receptor kinetics, tissue binding affinity, and stability of mometasone furoate. J. Pharm. Sci., v.93, n.5, p.1337-50, 2004.

WIEDERSBERG, S.; LEOPOLD, C. S.; GUY, R. H. Bioavailability and bioequivalence of topical glucocorticoids. Eur. J. Pharm. Biopharm., v.68, n.3, p.453-466, 2008.

Received for publication on $07^{\text {th }}$ August 2008 Accepted for publication on $24^{\text {th }}$ August 2009 